\title{
Microtopography of the eggshell of Menacanthus eurysternus (Phthiraptera: Amblycera)
}

\author{
Shweta Rajput ${ }^{1}$, Nidhi Gupta ${ }^{2}$,Vikram Khan ${ }^{2}$, Arun Kumar Saxena ${ }^{2 *}$ and V. D. Joshi ${ }^{1}$ \\ ${ }^{1}$ Department of Zoology, Government P. G. College, Kotdwara (Uttrananchal), INDIA \\ ${ }^{2}$ Department of Zoology, Government Raza Postgraduate College, Rampur-244901 (U.P.), INDIA \\ *Corresponding author. E-mail: akscsir@ rediffmail.com
}

\begin{abstract}
The egg laying sites, pattern and the egg morphology (SEM) of an amblyceran louse parasitizing Bank Myna (Acridotheres ginginianus) have been recorded. Unlike most of the species of the genus, Menacanthus studied so far, the eggshell of $M$. eurysternus lacks the apophyses (bristle like outgrowths arising from anterior portion of the eggshell). However, the opercular disc of $M$. eurysternus bears a polar thread and the micropyles are set along the opercular rim.
\end{abstract}

Keywords: Phthiraptera, Amblycera, Egg morphology

\section{INTRODUCTION}

Phthirapteran eggs are highly polymorphic and their egg chorion often exhibits sculpturing/ ornamentation. Markings present on the egg cases are generally species specific and may be used to differentiate the species. Balter (1968) has indicated the role of egg morphology as a guide to louse taxonomy. A scrutiny of literature indicated that microtopography of the eggshells of some species belonging to genus Menacanthus has been studied by the workers (Balter, 1968; Bilinsky and Jankowska, 1987; Zawadzka et al., 1997; Beg et al., 2004; Kumar et al., 2007). In the present report, an attempt has been made to record the egg morphology of yet another species of Menacanthus (M. eurysternus), parasitizing Bank Myna, Acridotheres ginginianus and to compare its architecture with the other species of genus Menacanthus, already described by earlier workers.

\section{MATERIALS AND METHODS}

As many as, 100 Bank Myna were examined for the presence of M. eurysternus, during 2004 to 2005. Out of these, 13 heavily infested birds were examined under megascope to note common egg laying sites. Feathers bearing eggs of M. eurysternus were further examined to record the egg laying sites of the louse. Few feathers bearing fresh eggs (pearly white in appearance) were gently cut from host body. The cementing material was gently broken (under stereozoom trinocular microscope) with the help of extremely fine entomological pins (sharprened by rubbing on a combination stone). The eggs were fixed in $2.5 \%$ gluteraldehyde, post fixed in $0.2 \mathrm{M}$ phosphate buffer, critically dried, arranged on stub (covered with double sided cellotape), gold coated and viewed under Scanning Electron Microscope at AIMS, New Delhi. Since, the Bank Myna is known to harbour four phthirapteran species, the adult females of $M$. eurysternus were dissected in insect Ringer's solution to take out fully developed ova, for matching purpose.

\section{RESULTS AND DISCUSSION}

M. eurysternus lays maximum number of eggs on the breast region, followed by neck, back, nape and abdominal feathers. Very small percentage of eggs were found on wings, legs, head and tail region. Eggs are laid on the base of small feathers, close to rachis. Eggs remain glued vertically parallel to axis of rachis (angle nearly $0^{\circ}$ $5^{\circ}$ ). Eggs are glued to the rachis through lateral side and the rear end of egg remains exposed.

Freshly laid eggs of M. eurysternus are pearly white in appearance. They appear elongated pear shaped in appearance (1.3-1.4 mm long). Except some faint hexagonal marks, which occur near the egg mouth, entire egg chorion as well as operculum appears to be smooth in nature (devoid of granulations, pits or other kind of sculpturing). The eggshell is devoid of any kind of apophyses (bristle like structure). The egg mouth is capped with an conical opercular disc (free from markings/ sculpturing) (0.24 $\mathrm{mm}$ in diameter). However, the apical end of operculum is produced into a large thread like structure (the "polar thread", measuring $0.7 \mathrm{~mm}$ in length). The polar thread of $M$. eurysternus appears single solid structure and does not seems to be made up of several intertwined threads. It gradually tapers apically. Sixteen to eighteen micropyles (which enable the entry of sperm and ensure ventilation) occur along the opercular rim. Each micropyle is button shaped structure and is 
separated by vertical ridges. The vertical ridges and the ridges arising from micropyles are joined by frill like horizontal ridges. Rear end of the eggshell is beset with a beehive like structure called "stigma". The latter contains 18-20 pits, which presumably lead into canals. Generally, the structure of stigma of phthirapteran egg is difficult to demonstrate, as the latter remains concealed in cementing material (used by lice to glue the eggs). Mechanism of destruction of cementing material to expose the stigma often causes destruction of the latter. Survey of literature shows that the egg shell of chicken body louse, $M$. stramineus have been studied by many workers (Balter, 1968; Bilinski and Jankowska, 1987; Saxena et al., 1993 and Zawadzka et al., 1997). The anterior $1 / 3$ portion of the egg shell of $M$. gonophaeus is faint beset with many bristle like structures (called apophyses); the apophyses belonging to lowermost row bear inverted disc; conical operculum bears hexagonal ridges and its tip is produced into a long polar thread; the latter consists of several intertwined threads).

Eggshell of crow louse, M. gonophaeus resemble to that of M. stramineus to a greater extent but the apophyses occur on $1 / 2$ of the anterior portion of egg shell and less numerous in number than that of $M$. stramineus (Beg et al., 2004).

The eggshell of poultry louse, M. cornutus exhibits pitted appearance (Kumar et al., 2007). Its egg mouth is fringed with only two rows of apophyses (those belonging to outer row hang outwards). The conical operculum bears distinct hexagonal ridges and its apical end is produced into long solid polar threads.

The eggshell of $M$. kalatitar appears similar to that of $M$. cornutus. They are similar in nature, number and arrangement of micropyles, number of apophyses. The only difference is in the nature of polar thread. The polar thread of M. kalatitar is thin and long while polar thread of $M$. cornutus is thick and short.

Thus, the nature of eggshell of common Myna louse, $M$. eurysternus differs from those other species of Menacanthus in pear shaped appearance, complete absence of apophyses, and occurrence of micropyles on opercular rim and separation of micropyles by ridges.
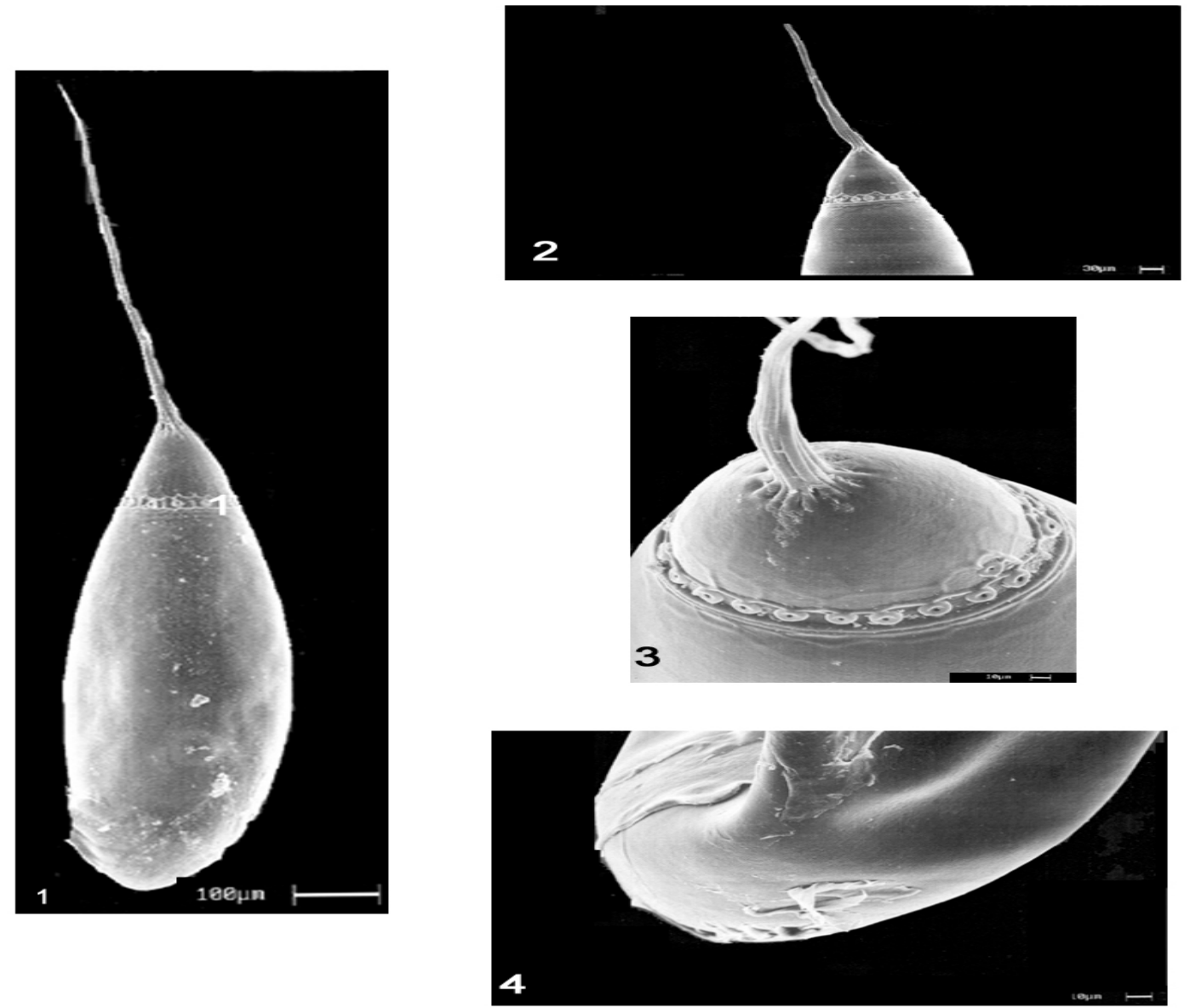

Plate 1. 1. SEM photograph of the entire egg shell of M. eurysternus, 2. Enlarge lateral view of anterior end of the egg shell of M. eurysternus; 3. Enlarge apiacl view of the opercular disc of M. eurysternus; 4. Rear end of the egg shell of M. eurysternus showing stigma. 
Present studies and the existing literature shows that the markings present on phthiratperan eggs are species specific and can be used for diagnosis the species. However, the examination of the eggshells of many more species of Menacanthus (parasitizing diverse hosts) will further demonstrate the role of egg morphology as a guide to louse taxonomy.

\section{ACKNOWLEDGEMENTS}

Authors thank the Principal, Govt. Raza P. G. College, Rampur for laboratory facilities, Head, SEM unit (IIT Roorkee) and the Council of Scientific and Industrial Research, New Delhi, India for providing financial support to Dr. A. K. Saxena, through sanctioning the project no. 37/ 1298/ 07/EMR II.

\section{REFERENCES}

Balter, R.S. (1968). The microtopography of avian lice eggs. Medical Biology (London), 18: 166-179.
Beg, S., Singh, S. K., Kumar, S., Gupta, N. and Saxena, A. K. (2004). Nature of the eggshell of phthirapteran ectoparasites infesting house crows. Rivista di Parassitolgia XXII (LXVI)N 1: 41-49.

Bilinski, S. M. and Jankowska, W. (1987). Oogenesis in the bird louse (Eomenacanthus stramineus) (Insecta, Mallophaga). I. General description and structure of the egg capsule. Zoologische Jehruberg Anatomische, 116: 1-12.

Kumar, S., Gupta, N. and Saxena, A. K. (2007). Microtopography of the eggs of two poultry lice. Indian Veterinary Journal, 84: 578-580.

Saxena, A.K., Trivedi, M.C., Kumar, A. and Rawat, B.S. (1993). Egg morphology of three amblyceran poultry lice (Insects, Phthiraptera). Rudolstandt. Nat. Hist. Schr., 5:65-68.

Zawadzka, M., Jankowska, W. and Bilinski, S. M. (1997). Eggshells of mallophagans and anoplurans (Insecta: Phthiraptera): morphogenesis of specialized regions and the relation of F-actin cytoskeleton of follicular cells. Tissue and cell, 29: 665-673. 